\author{
Ивана Ћирић \\ докторанд Филолошког факултета \\ Универзитет у Београду
}

UDC: 004.738.52:7.01

DOI: $10.18485 /$ dh.2015.1.ch8

\title{
ДИГИТАЛНА ЕСТЕТИКА УМЕТНИЧКОГ ПРАВЦА НЕТ.АРТ
}

\section{Сажетак}

Интересовање за уметничко изражавање коришћењем нових технологија јавља се 60-их година XX веkа. Глобална популаризација технолошког оруђа, посебно оko 1997. године изнедрила је нови правац нет.арт који врло брзо постаје карактеристичан феномен интернет мреже. У оквиру рада ће бити приказана афирмативна прича о његовом настанку и развоју а биће речи и о главним карактеристикама правца који не само да користи интернет као медијум већ и као локацију и материјал. Биће предочена главна разлика између нет арта - што је глобалан назив за све врсте дигиталних, електронских и медијских уметности које су на било који начин повезане са мрежом и нет. арта, коме је оруђе уједно и објекат манипулације па га то чини оригиналним по својој концепцији. У тексту је посебно разматрана естетика дела нет. арт уметника са становишта да је овај правац тешко валоризовати с обзиром да није саставни део традиционалне уметности. Додатно ће бити истражени изазови представљања, чувања и архивирања уметничких дела насталих специфичним уметничким интервенцијама као и могућност израде одређеног методолошког калупа за ову врсту уметности.

Кључне речи: Нет.арт, Дигитална уметност, Естетика, уметник, интернет, мрежа

Када говоримо о уметности претежно говоримо о сликама. Приступ феномену слике се мењао током историје. Радикално питање о промени статуса слике у савременој уметности први је поставио Готфрид Боехм (Gottfried Boehm) у есеју „Повратак слика“. ${ }^{1}$ Он сматра да смо ушли у период апсолутне присутности слика у савременом свету. Појава Iconic Turn, присутна у визуелним уметностима од краја 19. века, враћа слици смисао у оквиру њене властите логике.

1 Boehm, Gottfried. Povratak slika; Vizualni studiji - Umjetnost i mediji u doba slikovnog obrata, ur: Purgar, Krešimir. Zagreb: Cvs centar za vizualne studije, 2009. Print, str. 3-23. 
Као што је Витгенштајн метафизику језика деконструисао смештањем суштине језика у комуникацијска правила говорника који говоре истим језиком, тако се и Iconic Turn може разумети као једна стратегија ослобађања слике од њених историјских наслага смисла.

Према критеријуму трајности, артифицијелности, симболике као и осталим слојевима значења, слика је пре свега - комуникацијски медиј. Слика као информација претходи сваком њеном друштвеном и културном значењу. Зашто би таква слика уопште требала да има било које значење сем онога које произилази из визуелно предочене информације? Одговор на ово питање се мењао током векова а данас постаје све неизвеснији и нејаснији са појавом урањајућих слика, како их је назвао Оливер Грау. ${ }^{2}$

Давна појава Интернета и употреба World Wide Web-a (1995. године) изнедрила је многе до тада непознате видове друштвене интеракције и уметничког изражавања.

Све је већа распрострањеност различитих синтагми са префиксом дигитално, виртуелно и сајбер. Те тако имамо, дигитални простор, сајбер заједнице, дигиталну уметност, сајбер идентитет... Наведени примери говоре у прилог томе да је нови комуникацијски медиј (интернет) стекао мноштво својих присталица. Један од разлога за то је свакако чињеница што се интернет врло брзо показао као плодно тло за „пресликавање“ стварности. Овај медиј је артикулативно спојио текстуалне, аудио-визуелне елементе при томе перспективно омогућавајући висок степен интерактивности и слободу употребе (неки аутори ову слободу називају „демократизацијом“ употребе техно-друштвених пракси).

Нова култура која је омогућила убрзани развој медија или vice versa, користи и нова средства да би комуницирала у оквирима друштва. Она је донела и нове „синониме“ - „видим“ је заменило - „схватам“, „објаснити“ данас значи - визуелизовати. Данашња култура „мисли“ у сликама. Заједно са новим перспективама дошла је и нова логика. Наиме, Пјер Леви у разматрању значења - виртуелног, види само „трагање за очовечењем“. Дакле, виртуелно можемо схватити као нови свет, промену, која увећава моћ човека да влада собом и стварима. Хипотетичко ново оружје које стоји на располагању уметнику.

2 Grau, Oliver. Virtuelna umetnost. Beograd:Clio, 2008. Print. 
Сведоци смо тренутног распрострањеног поља деловања уметника који користе нове технологије и њихове многобројне предности. Нови начини изражавања, интерпретације, поимања и продаје уметничких творевина су ипак само сегмент онога што бисмо могли назвати сајбер уметношћу. Читав сет карактеристика нових медија и нових корисника само делимично осликава оно што се у популарном дискурсу назива сајбер културом. Мапирање различитих приступа уметности, посебних видова „коришћења“ Интернета и нових медија ${ }^{3}$ захтева подробно испитивање свих категорија експресије са уметничком тенденцијом.

Интересовање за уметничко изражавање коришћењем нових технологија јавља се 60-их година XX веkа. Глобална популаризација технолошког оруђа, посебно oko 1997. године изнедрила је нови правац Нет.Арт који врло брзо постаје карактеристичан феномен интернет мреже. Данас се о њему мало говори али га не смемо занемарити јер је у свом опусу садржао врло важне импликације и предикције друштвеног и идеолошког делања. Као што је рекао један од истакнутих писаца о Интернет уметности „Писање о уметности на Интернету је као да покушавамо речима да изразимо неки изузетно нестабилан феномен. Ова уметност је нераскидиво везана за развој самог Интернета, вожње торента бесног технолошког напретка који враћа у илуминацију визију модернизма, отетог од материје и баченог у етар, постајући тако изненада и радознало нов.... "Уметност" сама по себи је израз спора - одбачена од неких који су називани "нет уметници" - и овде се користи само условно речено, као погодан термин којим се може објаснити велики број феномена. О кохерентности овог термина се може судити тек касније. "Нет.арт" је термин који је постао повезан са малом групом раних практичара и са одређеним стилом, и не може се применити на онлајн уметности у целини. Ја ћу зато користи, као што сам рекао, без жеље да правим велике тврдње, термин "интернет уметност'“4

3 Nenić, Iva. Kultura Sajber prostora. Web. 9. dec. 2015. http://www.bos.rs/cepit/evolucija/ $\mathrm{html} / 5 /$ sajberkultura.htm

4 Stallabrass, Julian. Internet Art:The Online Clash of Culture and Commerce. Londres, Royaume-Uni: Tate Publishing, 2003. Print, str. 10-11. 
Свака заједница има свој историјат, неку причу или фантазију коју преноси својим члановима, присталицама и другима. Ова прича обично садржи неке карактеристичне моменте у њеном настајању и имена личности који су сведоци њене повести. Настанак термина Нет. арт можемо са великом сигурношћу утврдити захваљујући њеним творцима од којих још увек нисмо историјски удаљени.

Порекло термина и причу која га обавија можемо пратити захваљујући московском уметнику Алексју Шулгину (Aleksei Shulgin) који почетком 1997. године обзнањује 5 причу о настанку термина. Наиме, у децембру 1995. Вук Ћосић нет.уметник из Љубљане добија поруку анонимног пошиљаоца. Због некомпатибилности софтвера, текст који се приказао изгледао је као абракадабра АСцИИ. ${ }^{6}$ Само је један фрагмент имао некаквог смисла и он је изгледао је отприлике овако: [...] J8 г\#|\;Нет. Арт\{-^с1 [...]. Вук је био прилично задивљен јер је само име Нет. Арт осликавало оно чиме се он тада бавио. Одмах је почео да користи овај термин а после неколико месеци је проследио мистериозну поруку пријатељу Игору Марковићу који је успео да је дешифрује. Текст који се појавио био је прилично контраверзан манифест у коме аутор оптужује институције традиционалне уметности за разне грехе и проглашава слободу самоизражавања и независност уметника на интернету. Текст није био толико интересантан али је сам термин Нет.Арт индиректно оживео једну грану уметности која је тек била у повоју. Како тврди Шулгин, а на велику жалост историчара уметности, манифест је у целости изгубљен након краха Марковићевог хард-диска у лето 1996. године. Сам Алексеј је изјавио да му се јако допада ова чудна прича и да одлично илуструје чињеницу да је свет у коме живимо много више од онога што знамо и наслућујемо. Ћосић, ову врсту уметности дефинише на следећи начин: "Нет.арт се ни у ком случају не може сматрати систематичном доктрином, али ипак конституише школу." Џозефина Бос-

5 Shulgin, Alexei. Net.art - the origin in: Nettime, 18. March 1997. Web 8. dec. 2015. http:// www.nettime.org

6 ASCII - American Standard Code for Information Interchange - Амерички стандардни код за размену података.

7 Непознат извор. 
ма (Josephine Bosma), теоретичарка уметности и уредница часописа за ново-медијску уметност, ${ }^{8}$ мало ближе појашњава овај термин и праксу коју је подразумевао: "Без обзира колико уметници мрзели термин и без обзира колико одбијали да га користе, остали ће то и даље чинити. Разлог за то је вероватно што у време када се појавио термин Нет. арт није било уобичајене терминологије за уметност креирану помоћу или унутар Интернета још увек, иако су уметнички пројекти на интернету већ одавно постојали. Уметност креирана помоћу Интернета би се једноставно звала медијска уметност или електронска уметност, што су термини који не покривају специфичне интервенције на мрежи како то чини Нет.арт, са или без тачке."

Мађутим, чини се да су, сами уметници ипак правили разлику између Нет.арта са тачком и без тачке. Анализирајући уметничке изразе из домена Нет арта и неке од њихових изјава можемо закључити да би Нет арт био генерални израз који користимо да опишемо дело за које је интернет, шеб или виртуелни простор унутар рачунара неопходан или пак довољан услов док би Нет.арт био термин којим би описали дела оних уметника који се мање или више поистовећују са интернет мрежом.

У првом случају Нет је и довољан и неопходан услов за гледање/ доживљај/учествовање. Уметничка остварења из ове групе не морају нужно бити приказана преко интернет мреже, уметник их може нарезати и послати поштом коме год хоће. Међутим, без обзира колико интегралан део интернет мреже ово остварење било, послужићемо се Дишановском филозофијом - то је Нет арт ако је уметник имао манеру да буде Нет арт.

Овај вид уметности није револуција концепта - јер би се ту старе ствари на нови начин објашњавале, он је револуција оруђа где уметници стварају нове ствари које би желели да истраже. Главне карактеристике би биле - флуидност, хибридност, мултиплицирање.. све ово карактерише већину најбоље уметности на нету. Паралеле

8 CREM - Collaborative Research into Electronic Art Memes - Заједничка истраживања у електронској уметности Мемес

9 Bosma, Josephine. The dot on a Velvet Pillow. 2003. Web. 10. dec 2015. http://www.netart.org/netart 
можемо повући са Дадом, Флуксусом, концептуалном уметношћу, али ту је увек отворена дебата.

У погледу карактеризације другог случаја - Нет. Арта-њега је теже разумети и процењивати, јер није у питању традиционална уметност и јер се тешко уклапа у калупе традиционалне уметности. Уметност Нет. Арта је динамичка и увек је у развоју/процесу. Са сваким новим технолошким оруђем она постаје другачија. Другачија „слика“.

Конференција „Net.art per me“ одржана у Трсту 1996. године је била прво званично окупљање мале групе онлајн пионира на којој су дискутовали о својим активностима. Како Вук Ћосић наводи у својој књизи Net.art per me ${ }^{10}$ уметничко-политички вакум у Словенији у то време је најзаслужнији што је нет. арт постао део официјелне историје Бијенала. Одабир уметника за учествовање на овој манифестацији је проузрокова „злу крв“11 да је читав процес стигао до Министарства културе. Словеначки павиљон у оквиру Бијенала у Венецији 1996. године је кустосирала Аурора Фонда и на њему су по први пут представљени радови Вука Ћосића и италијанских уметника окупљених око 0100101110101101.org. „Готова документа“ рад Ћосића на овом Бијеналу, којим он приказује потенцијал, тада новог медијума, по први пут отвара питање галеријског приказивања нет.арта. Иако је изложена поставка садржала и компјутер, потребно је било направити максималне компромисе у односу на оригинални, првобитни контекст, како би се ово дело прилагодило галеријском простору. ${ }^{12}$ Дела других уметника нет.арта на у Словеначком павиљону, попут Хита Бантинга Тома Џенингса Алексеја Шулгина и група 0100101110101101.org, Џоди и РТМарк суочена су са истом проблематиком.

„Интернет уметност“ дефинисала је нову етику. Овде није реч о реформи категорија основних вредности уметности већ је реч о неопходности промена у перцепцији садашњих потреба друштва. Данас је уметност суочена са неограниченим могућностима вршења сопствених функција ван институционалног оквира, ван музеја. Требало је времена да се осведочимо да је Марло био у праву када је рекао да је музеј - само књига слика, а данас, захваљујући технолош-

10 Ćosić, Vuk. Net.art Per me. Venice: MGLC, 2001. Print, str. 13.

11 Isto.

12 Isto, 14 
ком напретку и могућностима миксовања различитих медија - смо у могућности да слици додамо звук, гест и нови простор за живот.

Као што је Дерида показао на примеру интертекстуалности текстова који се међусобно надовезују и односе један на други у историји метафизике као историје писма, аналогно се може говорити и о интерпиктуралности слика у медијском окружењу у савременом добу. Слика се више не односи на неку постављену реалност спољашњег или унутрашњег света, него се слике односе једна на другу. Овај бесконачни семиотички круг одређује савремену културу и уметност слике па самим тим и уметности.

Како је истакао Узелац Милан, време класичне естетике јеуправо завршено. Живимо у времену после класичног "сви напори усмерени на осмишљавање уметности и њене праксе а у доба кад је сваки разлог дешавања под неким знаком питања - могу се сабрати као посткласична размишљања и свака филозофија уметности на њиховом тлу може се одредити као посткласична естетика“. ${ }^{13}$ Иако је познато да филозофија разматра једанаест конотација појма форме, која је једна од кључних естетичких категорија, осврнућемо се само на две, посебно значајне и примењиве на естетику дигиталних дела. Форма као израз функције о којој су писали Хомер и Сократ, коју је Гропијус разумео као лепоту функционалности у случају дигиталне уметности је можемо разматрати као одређени вид органицизма. Пример форме као израза функције можемо видети на делу Алексеја Шулгина под називом „386 DX“. Ово дело представља први светски сајберпанк рок бенд. Састоји се од једног компјутера у коме се налази миди софтвер и у оквиру кога су музички и вокални инструменти синтетисани у реалном времену користећи се „text-to-speech“ програмом. Овај „бенд“ одржао перформансе на многим локацијама у Европи, Азији и Аустралији. Уметник би га изложио на прометном месту а пролазници су могли да чују музику. ${ }^{14}$ Овим делом уметник је желео да прикаже могућности нове технологије а у исто време и да оспори нужност њеног постојања. Групи РТМарк су могућности мреже послужиле да развије креативне саботаже корпоративних продукта и културе ${ }^{15}$

13 Uzelac, Milan. ESTETIKA. Novi Sad, 2003. Print, str. 3.

14 Ćosić, Vuk. Net.art Per me. Venice: MGLC, 2001. Print, str. 38-41.

15 Isto, 34-37. 
а групи Џоди да се помоћу кодирања поигравају са компјутерским игрицама и програмима, радикално мењајући њихове изворне кодове и интерфејсе. Ове екстремне дигиталне интервенције потпуно дестабилизују однос између компјутерске технологије и корисника. ${ }^{16}$

Друга конотација појма форме је игра - као естетска форма или по речима Рожеа Кајоа - Покажи ми како се играш па ћу ти рећи ко си.У овом контексту можемо разматрати „игру“ групе 0100101110101101. org. Њихову уметност најбоље карактерише прича по којој су и постали познати. Наиме, они су „украли“ целу нет арт галерију са сајта Hell.com, која није била јавно доступна и могло јој се приступити само путем шифре. Урадили су идентичну копију ове галерије и учинили је јавно доступном. И поред законских корака које су власници предузели, ова галерија је још увек доступна. Можемо их сматрати претечом хакера а њихова „игра“ је заправо изјава да свакоме треба да буде јасно да у доба дигиталне уметности више не постоји ни оригинал ни дупликат оригинала. Они овим подвлаче свој став у борби против „тржишта“ уметности које жели да одржи „ауру“ над делима уметности како би имало комерцијалне користи од ње. ${ }^{17}$

Обзиром да разумевање културе и друштвених односа (било прошлих или садашњих) представља један од задатака историје уметности, није ли онда она дужна и да разуме и објасни нову (назовимо је - дигиталном) културу? Да проучи, представи и сачува те нове слике? Дошли смо до можда најважнијег питања - како сачувати, конзервирати, дела нове, интернет уметности за будућа времена? Иако су многи нет уметници своја дела излагали и представљали јавно а у многим случајевима и користећи веома скупу опрему која би подржавала њихову идеју, проблем излагања је постојећи проблем. Да би се једно дело нет арт уметника изложило на било који од конвенционалних начина неоспорно мора бити деконтекстуализовано. Деконтекстуализацијом ово дело губи своју намену и губи се „спонтаност слободног сурфовања“"18 Даље, постоји још неколико актуелних изазова у вези са интернет уметношћу. Још увек није осмишљен

\begin{tabular}{ll}
\hline 16 & Isto, 32-33. \\
17 & Isto, 18-21. \\
18 & Isto, 14.
\end{tabular}


адекватан метод за њено документовање и чување. Јер „како архивирати нешто што је само по себи флуидно, интерактивно, процесуално и динамично?“ како је истакао Оливер Грау. ${ }^{19}$ Чување дела интернет уметности је отежано јер је процес доста отежан у односу на дела традиционалне уметности и захтева бележење и чување целокупног процеса, свих елемената уметниковог изражавања-делања а не само крајњи продукт. Обзиром да се ова дела често наменски прилагођавају простору где ће бити изложена она се самим тим мењају, мења се процес израде тј. само дело. Дакле било би потребно забележити и све фазе измене и надоградње, целокупну генезу једног дела, што би методолошки и финансијски био врло захтеван подухват.

Његов тим је још 1998. године оформио прву базу података интернет уметности али од тада није било значајнијег напретка, без обзира на многобројне фестивале дигиталне уметности и све већу популарност ове врсте уметности. Можда препрека лежи у томе што „музеји избегавају да уврсте дела дигиталне уметности у своје колекције, а дугорочни концепти за сакупљање виртуелне уметности и сарадња са, на пример, информатичким центрима, музејима технологије, и произвођачима опреме, једноставно још увек не постоји" како је изјавио Грау у својој књизи. ${ }^{20}$

Нови век створио је и нову културу која је створила нове форме. Наш је задатак да их негујемо и да допринесемо њиховом даљем развоју, да је адекватно забележимо, опишемо, прикажемо, да би наши наследници и неки будући историчари, теоретичари и уметници имали довољно материјала када буду писали нову историју уметности.

\section{Literatura}

Boehm, Gottfried. Povratak slika; Vizualni studiji - Umjetnost i mediji u doba slikovnog obrata, ur: Purgar, Krešimir. Zagreb: Cvs centar za vizualne studije, 2009. Print.

Bosma, Josephine. The dot on a Velvet Pillow. 2003. Web. 10. dec 2015. http://www. net-art.org/netart

Grau, Oliver. Virtuelna umetnost. Beograd:Clio, 2008. Print.

19 Grau, Oliver. Virtuelna umetnost. Beograd:Clio, 2008. Print, str. 259.

20 Isto. 
Nenić, Iva. Kultura Sajber prostora. Web. 9. dec. 2015. http://www.bos.rs/cepit/ evolucija/html/5/sajberkultura.htm

Stallabrass, Julian. Internet Art:The Online Clash of Culture and Commerce. Londres, Royaume-Uni: Tate Publishing, 2003. Print.

Shulgin, Alexei. Net.art - the origin in: Nettime, 18. March 1997. Web 8. dec. 2015. http://www.nettime.org

Uzelac, Milan. ESTETIKA. Novi Sad, 2003. Print.

Ćosić, Vuk. Net.art Per me. Venice: MGLC, 2001. Print.

\author{
Ivana Ciric \\ doctoral student at Faculty of Philology \\ University of Belgrade
}

\title{
DIGITAL AESTHETICS OF THE ARTISTIC MOVEMENT NET.ART
}

\section{Summary}

The interest in artistic expression by using new technology arises around 1960s. Global popularization of technological tools, especially around 1997, spawned a new direction - net.art which quickly becomes a distinctive phenomenon of the Internet network. As a part of the paper an affirmative story of its creation and development will be displayed and it will be discussed about its main characteristics regarding that this movement not only uses the Internet as a medium, but also as a location and material. The main differences between net art - which is a global name for all types of digital, electronic and media arts that are connected in any way with network and net. art, which use network as a tool and as an object of manipulation and thus makes it original in its conception, will be presented. The text specifically discusses aesthetics of net.art works from the standpoint that it is difficult to valorized them regarding that these works are not a part of the traditional arts. Further more, the challenges of representation, storage and archiving of this kind of art works will be explored as well as the possibility of making a certain methodological approach for this kind of art.

Key words: Net.art, digital art, aesthetics, artist, internet services, network 